\title{
MEMBANGUN CITRA MADRASAH MELALUI PROGRAM KELAS UNGGULAN DI MTSN 2 BANDAR LAMPUNG
}

\author{
DEVELOPING MADRASAH' IMAGE THROUGH \\ PREMINENT SCHOOL PROGRAM AT MTSN 2 OF \\ BANDAR LAMPUNG
}

\author{
Farida Hanun \\ Puslitbang Pendidikan Agama dan Keagamaan \\ Badan Litbang dan Diklat Kementerian Agama \\ Jl. MH. Thamrin N0. 6 Jakarta \\ E-Mail: farida_ridwan@yahoo.com
}

\begin{abstract}
A preminent class is a class consisting of selectedstudents based on strict requirements which are academic potency, IQ and highly sufficient student creativity. MTsN 2 of Bandar Lampung has held the preminent class program. The research is aimed at finding out implementation of the Preeminent class program at MTsN 2 of Bandar Lampung by using the qualitative method. The research shows that: a) The implementation of the preeminent class program can improve Islamic schools' image, b) Supporting factors of the implementation of the preminent class program are establishment of cooperation network between curriculum development team of MTSN 2 of Bandar Lampung and MGMP, availability of competent teachers, a proactive role of Islamic school committee in facilitating the implementation of the preeminent class program, c) Backstop factors are non-maximum students' readiness in following the preminent class learning process, some of the students have not actively used English, lack of reward from the headmaster on performance of the students teaching the preeminent class, some of the teachers have not used multimedia facilities to their maximum extent, d) The Ministry of Religion shall notice the need of facilities and infrastructures for Islamic schools organizing preminent class program, and the need of teachers' professionalism by holding workshops, seminars and work trainings.
\end{abstract}

Keywords: image, Madrasah, program, preminent class

\begin{abstract}
Abstrak
Kelas unggulan merupakan kelas yang berisi siswa pilihan yang diseleksi berdasarkan syaratsyarat yang ketat yaitu potensi akademik, IQ dan kreatitifitas siswa yang sangat memadai. MTsN 2 Bandar Lampung telah menyelenggarakan program kelas unggulan. Penelitian ini bertujuan untuk mengetahui pelaksanaan program kelas Unggulan di MTsN 2 Bandar Lampung dengan menggunakan metode kualitatip. Hasil penelitian menunjukkan bahwa: a) penyelenggaraan program kelas unggulan dapat meningkatkan citra madrasah, b) faktor pendukung pelaksanaan program unggulan adalah terbentuknya jaringan kerjasama tim pengembang kurukulum MTsN 2 Bandar Lampung dengan MGMP, tersedianya guruguru yang berkompeten, peranan komite madrasah yang proaktif dalam memfasilitasi pelaksanaan program kelas unggulan, c) faktor penghambatnya adalah kesiapan siswa yang belum maksimal dalam mengikuti pembelajaran kelas unggulan, sebagian siswa belum aktif berbahasa Inggris, kurangnya reward dari kepala sekolah terhadap kinerja guru yang mengajar kelas unggulan, sebagian guru belum maksimal menggunakan sarana multimedia, d) Kementerian Agama perlu memperhatikan kebutuhan sarana prasarana pada madrasah yang menyelenggarakan program kelas unggulan, dan perlunya peningkatan profesionalisme guru melalui penyelenggraan workshop, seminar dan lokakarya.
\end{abstract}

Kata Kunci: citra, madrasah, program, kelas unggulan 


\section{PENDAHULUAN}

Image masyarakat terhadap Madrasah sering diidentikkan dengan lembaga pendidikan kelas dua, tertinggal, dan kumuh. Selain itu citra negatif lain masih sering menempel di madrasah misalnya, kekurangmampuan madrasah membangun teamwork yang solid dalam mengelola pembelajaran, kekurangmampuan membangun hubungan antar personel yang kokoh, kurang membangun sinergi dengan berbagai pihak, resisten terhadap perubahan, ketidakmampuan menyesuaikan diri dengan tuntutan perubahan sosial, perkembangan teknologi pembelajaran yang sedang berlangsung.

Citra madrasah seperti itu harus diubah melalui unjuk prestasi. Untuk mewujudkan madrasah yang berprestasi perlu program-program strategis yang harus dikembangkan oleh madrasah dalam membangun citra positif sehingga ada percepatan peningkatan kualitas madrasah. Aspek-aspek yang harus diperhatikan oleh madrasah untuk mengantarkan madrasah yang memiliki citra positif diantaranya madrasah harus mempunyai visi dan misi yang jelas, memiliki SDM kepala madrasah dan guru yang mumpuni, manajemen yang profesional inovasi kurikulum, dan keterlibatan orang tua atau masyarakat.

Menciptakan trend dunia pendidikan pada saat ini menjadi sebuah tuntutan, oleh karena itu madrasah hendaknya lebih berani berinovasi. Keberanian berinovasi di bidang pendidikan di bawah Kementrian Agama menjadi sebuah tuntutan agar persepsi masyarakat yang menganggap madrasah sebagai pilihan kedua perlahanlahan akan hilang. Untuk menciptakan citra unggulan, madrasah perlu menampilkan suatu terobosan yang baru baik pada materi kurikulumnya, fasilitas, atau pengajarannya

Munculnya madrasah-madrasah yang unggul belakangan ini, berdampak pada animo kepercayaan masyarakat terhadap lembaga pendidikan "Madrasah" semakin meningkat. Terbukti dengan meningkatnya animo masyarakat untuk memasukkan anaknya di madrasah. Konsekuensinya, madrasah semakin ditantang untuk meningkatkan kualitas agar kepercayaan masyarakat tidak goyah dan semakin menguat citra positip madrasah.

Pada kasus di MTs N 2 Bandar Lampung, terlihat ada upaya-upaya yang dilakukan lembaga pendidikan tersebut dengan membawa citra kelas unggulan yang setidak-tidaknya citra tersebut memiliki makna, ingin mengangkat madrasah menjadi madrasah unggul dalam bidang prestasi akademik maupun unggul dalam bidang prestasi non-akademis

Kelas unggulan merupakan kelas yang berisi siswa pilihan yang dipilih berdasarkan syarat-syarat yang ketat yaitu IQ, potensi akademik, dan prestasiakademikyang sangat memadai dan bila diberikan pembelajaran yang baik diharapkan memperoleh hasil yang baik pula. ${ }^{1}$ Penerapan kelas unggulan merupakan implementasi dari undangundang Republik Indonesia no 20 tahun 2003 tentang Sistem Pendidikan Nasional menyebutkan bahwa: "warga negara yang memiliki potensi kecerdasan dan bakat

${ }^{1}$ Amin Mudi Utomo. 2012. Pengelolaan Pendidikan Karakter Kelas Unggulan di SMP Negeri 2 Cepu. Surakarta: Universitas Muhammadiyah Surakarta, h. 8 
istimewa berhak mendapatkan pendidikan khusus". ${ }^{2}$

Penyelenggaraan kelas unggulan bertujuan diantaranya: mengembangkan dan meningkatkan kualitas pendidikan, menghasilkan sumber daya manusia yang berkualitas, meningkatkan kemampuan dan pengetahuan tenaga pendidik, mengembangkan potensi yang ada di Sekolah, meningkatkan kemampuan untuk menghadapi persaingan di dunia pendidikan dengan menciptakan keunggulan kompetitif. $^{3}$

MTsN 2 Bandar Lampung merupakan salah satu madrasah yang telah menerapkan adanya kelas unggulan. Dalam penerapannya, kelas unggulan memiliki karakteristik yang berbeda dengan kelas reguler dalam pembelajaran, diantaranya: materi pembelajaran yang memiliki cakupan yang lebih banyak, waktu pembelajaran yang lebih lama dibandingkan dengan kelas reguler, pembinaan siswa dan lain-lain. Kaitannya dengan adanya kelas unggulan tersebut diharapkan mampu menghasilkan generasi yang unggul, berkualitas dan berakhlakul karimah.

Berdasarkan uraian di atas, penulis tertarik untuk melihat bagaimana membangun citra madrasah melalui program kelas Unggulan Di MTsN 2 Bandar Lampung. Permasalahan penelitian ini difokuskan pada bagaimana pelaksanaan program kelas unggulan dalam upaya peningkatan kualitas pendidikan dan Faktor-faktor apa saja yang mendukung

${ }^{2}$ Undang-Undang No 20 Tahun 2003 Tentang Sistem PEndidikan Nasional P asal 4

${ }^{3}$ Utomo. Op. Cit., h. 24 dan menghambat pelaksanaan perogram kelas Unggulan?

Tujuan penelitian ini adalah untuk mengetahui pelaksanaan program kelas Unggulan di MTs N 2 Bandar Lampung. Sedangkan manfaat penelitian ini diharapkan menjadi masukan sebagai bahan pertimbangan bagi pimpinan Kementerian Agama khusuanya Direktorat Pendidikan Islam dalam menentukan kebijakan pembinaan pendidikan di madrasah pada masa mendatang.

\section{Kajian Literatur}

Terkait dengan penyelenggaraan program kelas Unggulan, Puslitbang Pendidikan Agama dan Keagamaan tahun 2013 Telah melakukan penelitian tentang penyelenggaraan Madrasah-madrasah Unggulan. Penelitian ini lebih banyak menjelaskan bagaimana program-program unggulan diselenggarakan. Salah satu dari sekian banyak program-program unggulan yang dipaparkan pada madrasah-madrasah sasaran penelitian adalah program kelas Unggulan di MTsN Bukit Bukit Raya Bandara Lampung. ${ }^{4}$ Hasil penelitian menunjukkan model tata kelola unggulan telah melahirkan alumni yang berprestasi. Kompetensi akademik, moral dan skill digembleng khusu dalam kelas unggul dengan pembinaan instensif. Bahasa Arab, Inggris, matematika, dan tahfidz menjadi fokus utama Kelas Unggulan. Iklim pembelajaran di dorong berorienstasi meraih prestasi, berpacu

${ }^{4}$ Farida Hanun. 2013. Laporan Madrasah Unggulan di MTsN Bukit Raya Pekanbaru Riau. Jakarta: Puslitbang Pendidikan Agama dan Keagamaan Badan Litbang dan Diklat Kemeneterian Agama, h. 45 
menambah ilmu dan bersama membangun citra madrasah.

\section{Kerangka Teori}

\section{Membangun Citra Madrasah}

Menurut Kamus Bahasa Indonesia pengertian membangun adalah (a) bangkit berdiri, (b) mendirikan, (c) membina. ${ }^{5}$ Adapun madrasah menurut Zuhairini dimaknai sebagai tempat belajar yang mengajarkan ajaran-ajaran agama Islam, ilmu pengetahuan dan keahlian lainnya yang berkembang pada jamannya. ${ }^{6}$

Pemerintah khususnya Kementerian Agama telah menjelaskan pengertian madrasah, bahwa madrasah adalah satuan pendidikan formal dalam binaan pendidikan agama yang menyelenggarakan pendidikan umum dan kejuruan dengan kekhasan agama Islam yang mencakup Raudhatul Athfal, Madrasah Ibtidaiyah, Madrasah Tsanawiyah, Madrasah Aliyah dan Madrasah Aliyah Kejuruan. ${ }^{7}$

Selanjutnya citra pada hakekatnya adalah pemahaman kesan yang timbul karena pemahaman akan suatu kenyataan. ${ }^{8}$ Kotler mendefinisikan citra sebagai seperangkat keyakinan, ide dan kesan yang dimiliki orang terhadap suatu objek, di mana sikap dan tindakan seseorang terhadap suatu objek sangat dipengaruhi oleh objek

${ }^{5}$ Alwi Hasan, dkk. 2005. Kamus Besar Bahasa Indonesia. Jakarta : Departemen Pendidikan Nasional Balai Pustaka, h.480

${ }^{6}$ Zuhairini. 2004. Sejarah Pendidikan Islam. Jakarta: Bumi Aksara, h. 25

${ }^{7}$ Peraturan Menteri Agama (PMA) no 90 Tahun 2013 Tentang Penyelenggaraan Pendidikan Madrasah Pasal 1

${ }^{8}$ Op. cit., h. 667 tersebut. Hal ini memberikan arti bahwa kepercayaan, ide dan kesan seseorang sangat besar pengaruhnya terhadap sikap dan prilaku maupun respon yang mungkin akan dilakukan. ${ }^{9}$

Seseorang yang memiliki kepercayaan yang tinggi terhadap lembaga pendidikan tentunya akan mendaftarkan dan mempercayakan lembaga pendidikan tersebut menjadi tempat mendidik putraputri mereka, bahkan tidak menutup kemungkinan untuk mempengaruhi orang lain supaya mempercayakan pendidikan putra-putri mereka pada lembaga pendidikan tersebut.

Soebagio menjelaskan bahwa, terdapat beberapa manfaat apabila suatu lembaga pendidikan menampilkan citra positif diantaranya konsumen akan tumbuh sikap kepercayaan yang tinggi dan mampu menarik sanak famili jika citra lembaga pendidikan telah positif. ${ }^{10}$

Dengan demikian yang dimaksud dengan membangun citra madrasah adalah semua aktivitas yang diwujudkan untuk menciptakan kerja sama yang harmonis antara madrasah dan masyarakat melalui usaha memperkenalkan madrasah dan seluruh kegiatannya kepada masyarakat agar madrasah memperoleh simpati masyarakat.

\section{Program Kelas Unggulan}

Pada hakekatnya kelas unggulan adalah kelas yang menyediakan program pelayanan kusus bagi peserta didik dengan cara

9 Philip Kotler. 2006. B2B Brand Management. Berlin: Springer, h. 26

10 Soebagio Atmodiwiryo. 2000. Manajemen Pendidikan Indonesia. Jakarta: Ardadizya Jaya, h. 71 
mengembangkan bakat dan kreativitas yang dimilikinya untuk memenuhi kebutuhan peserta didik yang memiliki potensi kecerdasan dan bakat istimewa. ${ }^{11}$ Sedangkan menurut Direktorat Pendidikan Dasar yang ditulis kembali oleh Agus Supriyono adalah sejumlah anak didik yang karena prestasinya menonjol dikelompokkan di dalam satu kelas tertentu kemudian diberi program pengajaran yang sesuai dengan kurikulum yang dikembangkan dan adanya tambahan materi pada mata pelajaran tertentu. ${ }^{12}$

Selanjutnya menurut Suhartono dan Ngadirun, kelas unggulan adalah kelas yang dirancang untuk memberikan pelayanan belajar yang memadai bagi siswa yang benar-benar mempunyai kemampuan yang laur biasa. ${ }^{13}$ Tujuan penyelenggaraan kelas unggulan diantaranya: (1) mengembangkan dan meningkatkan kualitas pendidikan, (2) menghasilkan sumber daya manusia yang berkualitas, (3) meningkatkan kemampuan dan pengetahuan tenaga pendidik, (4) mengembangkan potensi yang dimiliki sekolah, (5) meningkatkan kemampuan untuk menghadapi persaingan di dunia pendidikan dengan menciptakan keunggulan kompetitif ${ }^{14}$

Menurut Syaiful Sagala, tujuan diselenggarakannya kelas khusus bagi siswa yang memiliki kemampuan yang menonjol adalah (a) pemberianperlakuanyangberbeda

${ }^{11}$ Aripin Silalahi. 2006. Program Kelas Unggulan. Jakarta: Sidikalang, h. 1-2.

12 Agus Supriyono. 2009. Penyelenggaraan Kelas Unggulan di SMA Negeri 2 Ngawi. Tesis, Universitas Sebelas Mare. Surakarta: Universitas Sebelas Maret, h. 13 .

${ }^{13}$ Suhartono dan Ngadirun. 2009. Penyelenggaraan Program Kelas Unggulan di Sekolah Dasar. Jakarta: Universitas Terbuka, h. 114

${ }^{14}$ Silalahi, op.cit., hlm. 9. dari setiap siswa yang memiliki kemampuan yang berbeda, (b) ada kesempatan bagi siswa untuk mengembangkan kemampuan yang dimilikinya, c) menimbulkan perasaan bebas dalam belajar sehingga terjadi hubungan yang harmonis antara guru dengan siswa dalam belajar. ${ }^{15}$

Kelas Unggulan harus memiliki karakteristik sebagai berikut: (1) masukan diseleksi diseleksi secara ketat dengan menggunakan kriteria yang dapat dipertanggung-jawabkan, (2) sarana dan prasarana menunjang untuk pemenuhan kebutuhan belajar dn penyaluran minat dan bakat siswa, (3) lingkungan belajar yang kondusif untuk berkembangnya potensi keunggulan menjadi keunggulan yang nyata, (4) memiliki kepala sekolah dan tenaga kependidikan yang unggul, baik dari segi penguasaan materi pelajaran, metode mengajar, maupun komiten dalam melaksanakan tugas, (5) kurikulum yang diperkaya, yakni melakukan pengembangan dan improvisasi kurikulum secara maksimal sesuai dengan tuntutan belajar, (6) rentang waktu belajar di sekolah yang lebih panjang dibandingkan kelas lain dan tersedianya asrama yang memadai, (7) proses pembelajaran yang berkualitas dan hasilnya selalu dapat dipertanggungjawabkan kepada siswa, lembaga, maupun masyarakat, (8) adanya perlakuan tambahan di luar kurikulum, program pengayaan dan perluasan, pengajaran remedial, pelayanan bimbingan dan konseling yang berkualitas, pembinaan kreativitas, dan disiplin, sistem asrama, serta kegiatan ekstrakurikuler lainnya, dan (9) pembinaan kemampuan

15 Syaiful Sagala. 2003. Konsep dan Makna Pembelajaran. Bandung: Alfabeta, h. 184 
kepemimpinan yang menyatu dalam keseluruhan sistem pembinaan siswa melalui praktik langsung dalam kehidupan sehari-hari. ${ }^{16}$

\section{METODOLOGI PENELITIAN}

Penelitian ini menggunakan metode kualitatif, ${ }^{17}$ yaitu prosedur penelitian yang menghasilkan data deskripsi berupa katakata tertulis atau lisan dari orang- orang dan perilaku yang dapat diamati. Lokasi penelitian dilakukan pada MTsN 2 Bandar Lampung. Pengumpulan data dilakukan dengan menggunakan beberapa teknik: a) studi dokumen; b) pedoman wawancara, c) daftar isian. Informan penelitian ini terdiri dari unsur-unsur kepala sekolah, wakil kepala sekolah bidang kurikulum, guru, dan siswa. Analisis data merupakan tindak lanjut dari semua tahap kerja di atas. Di lapangan, dengan bantuan pedoman wawancara dan studi dokumen, peneliti merekam, mencatat, mengkaji, melakukan check dan recheck, mengklasifikasi, serta mengembangkan dan mengabstraksi data dan informasi yang diperoleh dari responden. Data-data yang di himpun melalui wawancara mendalam, kuesioner dan studi pustaka diolah dan dirumuskan menjadi laporan penelitian.

\section{HASIL DAN PEMBAHASAN}

\section{Profil MTsN 2 Bandar Lampung}

Madrasah Tsanawiyah Negeri (MTsN) 2 Bandar Lampung (dulu dikenal dengan

${ }^{16}$ Ibid.,

${ }^{17}$ Lexy .J. Moleong. 2000. Metodologi Penelitian Kualitatif. Cetakan Keenambelas. Bandung: Remaja Rosdakarya, h. 45 nama MTsN 2 Tanjung Karang) didirikan pada tahun 1978 dan merupakan lembaga pendidikan nasional yang setara dengan Sekolah Menengah Pertama (SMP) di bawah naungan Departemen Agama RI, berdasarkan Surat Keputusan Bersama (SKB) Tiga Menteri Tahun 1975, yaitu Mendikbud, Mendagri dan Menag tentang peningkatan mutu pendidikan pada madrasah. Dan diperjleas pula dengan dikeluarkan SK Mendiknas RI Nomor : 054/U/1993, tentang penetapan bahwa MTs adalah SMP yang berciri khas Agama Islam. Penetapan ini membawa dampak positif bagi perkembangan madrasah sebab berimplikasi terhadap penerapan kurikulum.

Pada awal berdirinya MTsN 2 Bandar Lampung belum mempunyai gedung tersendiri masih menumpang pada gedung Pendidikan Guru Agama Negeri (PGAN) di Pahoman Bandar Lampung. Pada tahun 1985 resmi pindah dan menempati gedung sendiri diatas lahan tanah seluas $20.000 \mathrm{M}^{2}$ (2 Hektar) yang berada di Jalan Pulau Pisang No. 20 Kelurahan Korpri Raya Kecamatan Sukarame Kota Bandar Lampung Telp (0721) 780135.

Dari waktu ke waktu MTsN 2 Bandar Lampung terus melakukan peningkatan kualitas Sumber Daya Manusia (SDM) dan Proses Pembelajaran, sehingga Alhamdulillah pada tahun 1998 MTsN 2 Bandar Lampung mendapat predikat Nasional sebagai MTs Model dari Menteri Agama dan pada tahun 2004 ditetapkan sebagai pilot projek dalam pelaksanaan Kurikulum Berbasis Kompetensi (KBK).

MTsN 2 Bandar Lampung mendidik murid-muridnya agar dapat memperoleh bekal kemampuan dasar sebagai perluasan 
serta peningkatan pengetahuan agama dan keterampilan yang diperolehnya serta bermanfaat baginya untuk mengembangkan kehidupannya sebagai muslim dan menjadi anggota masyarakat serta warga negara yang sesuai dengan tingkat perkembangannya dan mempersiapkan mereka untuk dapat hidup yang bermanfaat dalam masyarakat. Oleh karena itu MTsN 2 Bandar Lampung merasa terpacu untuk terus berbenah hingga dapat menjadi Madrasah kebanggaan umat Islam khususnya dan masyarakat pada umumnya, yang pada akhirnya dapat menghasilkan lulusan-lulusan yang berkualitas dan dapat melanjutkan pendidikan ke jenjang SMA/ MA/SMK favorit.

Salah satu parameter untuk melihat keberhasilan MTsN 2 Bandar Lampung dalam menghasilkan lulusan-lulusan yang berkualitas, dapat dilihat dari alumni yang saat ini mampu memimpin berbagai institusi Pemerintahan, baik pada tingkat lokal maupun Nasional. Sebagai contoh pada tingkat lokal, Kepala Kementerian Agama Provinsi Lampung saat ini, yaitu: Drs. H. Rahman Harun, M.Ag, merupakan salah satu alumni yang dihasilkan oleh MTs Negeri 2 Bandar Lampung. Kemudian pada tingkat nasional, Menteri Kehutanan Republik Indonesia, Dr. Zulkifli Hasan, merupakan salah satu alumni terbaik yang pernah dihasilkan oleh MTsN 2 Bandar Lampung.

Geografis MTsN 2 Bandar Lampung berada pada posisi yang strategis. Indikasi strategisnya lokasi tersebut dapat dilihat dari beberapa faktor pendukung antara lain berdekatan dengan : 1) Institut Agama Islam Negeri (IAIN) Radin Intan Bandar Lampung, 2) madrasah Aliyah Negeri (MAN) 1 Bandar Lampung, 3) Perumahan KORPRI
Sukarame Bandar Lampung, 4) Puskesmas KORPRI Sukarame Bandar Lampung, 5) MIN Sukarame Bandar Lampung. Secara geografis Madrasah Tsanawiyah Negeri (MTsN) 2 Bandar Lampung berada di Jalan Pulau Pisang No. 20 Kelurahan Korpri Raya Kecamatan Sukarame Kota Bandar Lampung. Madrasah Tsanawiyah Negeri (MTsN) 2 Bandar Lampung terletak di lingkungan pendidikan dan perumahan penduduk. Dimana lingkungan masyarakatnya berpendidikan dan masih berpegang kepada budaya ketimuran yang masih terjaga dengan baik sehingga tercipta suasana sosial yang kondusif (terlihat ketika sore hari masyarakat sekitar berolah raga di lapangan madrasah).

Terkait aspek input atau peminat yang mendaftar di MTs Negeri 2 Bandar Lampung rata-rata bisa mencapai 1000 orang. Dan yang diterima dari tahun ke tahun antara 300 s.d 400 siswa. Jadi peminat sangat melebihi dari daya tampung yang ada. Maka jumlah siswa dari tahun ke tahun juga meningkat seiring dengan jumlah lokal yang dimiliki. Berikut daftar jumlah siswa selama 5 tahun terakhir. Dilihat dari banyaknya siswa yang masuk menunjukkan angka yang semakin naik. Tahun 2009/2010 jumlah siswa sebanyak 1038, jumlah siswa tahun 2010/2011 sebanyak 993, tahun 2011/2012 jumlah siswa 1107, tahun 2012/2013 jumlah siswa sebanyak 1257 dan jumlah siswa tahun 2013/2014 sebanyak 1310 siswa.

Pola rekruitmen siswa dimulai lebih awal di bulan April dengan menggaet peserta didik terbaik di MI atau SD-nya masing-masing dengan kualifikasi nilai rata-rata kelas 5 dan 6 minimal 75 atau peringkat 10 besar di kelasnya masingmasing. Calon siswa tersebut diseleksi/diuji 
secara tertulis kemampuan akademiknya (matematika, bahasa inggris dan IPA) dan praktik membaca Al Qur'an dan wawancara bahasa inggris. Selain itu, dalam penerimaan murid baru MTs Negeri 2 Bandar Lampung mengutamakan peserta didik baru berdasarkan seleksi akademik dengan tidak membedakan yang kaya maupun miskin. Untuk peserta didik Kelas Reguler tidak dipungut biaya alias gratis dan peserta didik Kelas Unggul dikenakan biaya bulanan yang bervariasi antara satu dengan yang lainnya sesuai dengan kesepakatan kemampuan orang tua.

Pada aspek kondisi guru, MTsN 2 Bandar Lampung memiliki tenaga pendidik sebanyak 88 orang meliputi PNS 74 orang (57 wanita dan 17 laki-laki) dan GTT 14 orang (10 wanita dan 4 laki-laki). Sedangkan pendidikan terakhir tenaga pendidik tersebut diantaranya ada yang lulusan Program Pasca Sarja (S2) sebanyak 15 orang (8 wanita dan 7 laki-laki), lulusan Strata Satu (SI) sebanyak 73 orang (59 perempuan dan 14 laki-laki). Beberapa diantaranya sedang melanjutkan Program Pasca Sarjana dan Strata Satu. Selain itu pendidik/guru mengajar sesuai dengan bidang studinya tapi masih dijumpai beberapa pendidik yang masih missmach disebabkan karena harus menyesuaikan sertifikasinya. Adapun kondisi tenaga kependidikankan, data menunjukkan dari 21 orang tenaga kependidikan yang terdapat di MTsN 2 Bandar Lampung, hampir ada 10 (47\%) tenaga kependidikan sudah berstatus PNS dan yang masih berstatus honorer tinggal 11 (53\%). Jika dilihat dari jenis kelamin, ada sekitar 9 orang yang berjenis kelamin lakilaki dan 12 orang perempuan
Untuk mencapai madrasah yang Unggul maka ketersediaan sumber daya manusia yang berkualitas tidak dapat ditawar-tawar lagi. Untuk mendapatkan guru yang berkualitasa di awali dari proses perekrutan guru. Untuk guru kelas unggul yang 4 (empat) mata pelajaran yaitu bahasa arab, bahasa inggris, matematika dan IPA tidak tergantung dengan guru PNS yang ada melainkan mencari yang memiliki kompetensi bidang studinya dan bisa berkomunikasi dengan menggunakan bahasa asing (arab atau inggris) walau belum PNS.

Adapun progran pengembangan guru MTsN 2 Bandar Lampung dilakukan melalui: pemberdayaaan staf, menempatkan personil yang dapat melayani keperluan semua siswa, penyediaan staf yang memiliki wawasan "School Based Manajemen", penyediaan kegiatan untuk pengembangan profesi pada semua staf, penjamin kesejahteraan staf dan siswa, serta penyelenggaraan forum atau diskusi untuk membahas kemajuan sekolah (School performance). Selai itu, guru juga didorong untuk meningkatkan kompetensinya melalui Diklatatau workshop yang diadakan oleh Kementerian Agama, Kementerian Pendidikan dan Kebudayaan maupun madrasah sendiri. Bahkan dengan menggunakan biaya sendiri seperti: kursus bahasa inggris dan belajar mengoperasikan komputer, LCD atau kursus internet.

\section{Ketersediaan Sarana Prasarana}

Salah satu keunggulan MTsN 2 Bandar Lampung adalah kelengkapan sarana dan fasilitas madrasah pendukung tercapainya mutu pendidikan. Sarana yang dimilki diantaranya ruang Kepala Sekolah, 33 ruang 
belajar (kelas), 2 Ruang Guru, Ruang Tata Usaha, Ruang Aula, Ruang Perpustakaan, Ruang Laboratorium IPA, Ruang Kesenian /keterampilan, Ruang Pendidikan Teknologi Dasar (PTD), Ruang Laboratorium Computer, Ruang Laboratorium Bahasa, Ruang UKS, Ruang Multimedia, Ruang BK, Ruang pramuka/Osis, Gudang, WC (Kepala Madrasah dan guru ada 4 buah, siswa ada 28 buah, Tempat Ibadah, 10 Kantin Sekolah, 3 lapangan Olah Raga, ruang Koperasi / Warung Madrasah, dan sarana Wifi.

Khusus sarana perpustakaan di MTsN 2 Bandar Lampung, memiliki beberapa fungsi yaitu sebagai media pendidikan, tempat belajar, pemanfatan teknologi informasi, kelas alternatif, dan sumber informasi. Selain itu. Perpustakaan juga dapat memberikan pengajaran dan pendidikan bagi siswa dan dapat membantu siswa dalam menyelesaikan tugas dari guru. Kelengkapan fasilitas perpustakaan diantaranya: kelengkapan koleksi bahan pustaka, pelayanan perpustakaan, keadaan ruangan yang memadai dan perabot dan perlengkapn perpustakaan.

Pengadaan sarana madrasah yang ada di MTsN 2 Bandar Lampung, seperti gedung madrasah tidak sepenuhnya diperoleh dari bantuan pemerintah. Ada beberapa fasilitas sarana yang dibangun melalui komite madrasah seperti 1 buah ruang guru, beberapa bangunan WC siswa, paving blok halaman atau lapangan madrasah yang luasnya lebih dari $1000 \mathrm{~m}^{2}$, taman dan sarana yang lainya seperti masjid. Pembangunan masjid dan madrasah diperoleh dari sumbangan/infak guru dan siswa setiap hari.

\section{Kebijakan Mutu Madrasah}

Menyadari beratnya tantangan yang dihadapi dunia pendidikan kita saat ini, berbagai upaya telah dilakukan pemerintah dalam rangka menyempurnakan sistem dan model pendidikan kita saat ini. Mulai dari penataan perangkat lunak (software) maupun perangkat keras (hardware). Upaya tersebut, antara lain dengan dikeluarkannya Undang-Undang nomor 22 dan 25 tahun 1999 tentang otonomi daerah, serta diikuti oleh lahirnya Undang-Undang nomor 20 tahun 2003 tentang Sistem Pendidikan Nasional. Lahirnya kedua produk Undang-Undang tersebut secara langsung berpengaruh terhadap manajemen pendidikan yang mencakup perencanaan, pelaksanaan, dan evaluasi.

Jika sebelumnya manajemen pendidikan merupakan wewenang pusat dengan paradigma top-down atau sentralistik, maka dengan berlakunya Undang-undang tersebut kewenangan bergeser dengan paradigma bottom-up atau desentralisitik, dalam sebuah wujud pemberdayaan madrasah. Argumentasi yang mendasari munculnya statemen adalah bahwa sangat diyakini untuk meningkatkan kualitas pendidikan sedapat mungkin keputusan dibuat oleh pihak-pihak yang berada di garis depan, yang bertanggung jawab terhadap pelaksanaan kebijakan.

Untuk menjawab semua kondisi dan harapan di atas, tidak ada jalan lain bahwa diperlukan sebuah paradigma baru dalam manajemen pendidikan. Sustainability dari semua kondisi dan harapan tersebut adalah diperlukannya perencanaan, pengelolaan, dan evaluasi pendidikan yang berbasis manjemen sekolah/madrasah. Pernyataan 
ini relevan dengan amanat Undang-Undang nomor 20 tahun 2003 pasal 52 ayat (1) yang menyatakan bahwa: "pengelolaan satuan pendidikan usia dini, pendidikan dasar, dan pendidikan menengah dilaksanakan berdasarkan standar pelayanan minimal dengan prinsip Manajemen Berbasis Sekolah/ Madrasah".

Dari penjelasan di atas maka MTsN 2 Bandar Lampung melaksanakan Kebijakan Mutu Madrasah dengan prinsip manajemen berbasis madrasah (MBM).Penerapan Manajemen Berbasis Madrasah atau Madrasah Based Management (MBM), diharapkan membawa dampak peningkatan efesiensi dan efektivitas kinerja madrasah, dengan menyediakan layanan pendidikan yang komprehensif dan tanggap terhadap kebutuhan masyarakat. Dengan Manajemen Berbasis Madrasah (MBM), madrasah diharapkan juga dapat meningkatkan efesiensi. partisipasi, dan mutu, serta bertanggung jawab kepada masyarakat dan pemerintah.

Sebagai bagian dari lembaga pendidikan formal dan merupakan salah satu tingkat satuan pendidikan di madrasah, pelaksanaan Manajemen Berbasis Madrasah (MBM) di Madrasah Tsanawiyah (MTs), memiliki karakteristik pelaksanaan yang dapat diketahui dari parameter sebagai berikut: (a) bagaimana MTs dapat mengoptimalkan kinerjanya, (b) bagaimana MTs dapat mengoptimalkan proses pembelajaran, (c) bagaimana MTs dapat mengoptimalkan pengelolaan sumber belajar, (d) bagaimana MTs dapat mengoptimalkan profesionalisme tenaga kependidikan, (e) bagaimana MTs dapat mengoptimalkan sistem administrasi secara keseluruhan.
Dalam menerapkan kebijakan mutu madraah, MTsN 2 Bandar Lampung terlebih dahulu membuat Analisis SWOT (Strength Weakness Opportunity Treath). Pertama, Strength (Kekuatan) meliputi guru yang memiliki kualifikasi S1 dan beberapa guru yang telah menyelesaikan S2, jumlah guru yang cukup, memiliki Kepala madrasah yang tegas dan visioner, jumlah murid yang banyak, animo masyarakat positif terhadap madrasah. Kedua, Weakness (Kelemahan) meliputi : ada beberapa guru yang kurang disiplin, dan ada beberapa murid yang prilaku negatif. Ketiga, Opportunity (Peluang) meliputi: tunjangan profesi guru bisa membuat kinerja guru meningkat, dan status madrasah dan sekolah umum yang sama. Keempat, Treath (Ancaman) meliputi: masih ditemukan warung internet (warnet) di dekat madrasah, ada play station/game di dekat madrasah, pengaruh narkoba dari luar madrasah, kenakalan remaja

\begin{tabular}{cr}
\multicolumn{2}{c}{ Kebijakan-kebijakan strategik } \\
yang dilakukan madrasah untuk
\end{tabular} mengimplementasikan visi, misi, dan tujuan di atas adalah: 1) membangun profesionalisme dengan pendidikan dan pelatihan, 2) memberdayakan setiap potensi dengan spirit ibadah, 3) menerapkan pola managemen yang transparan dan akuntabel dengan sentuhan budaya dan agama, 4) melejitkan setiap potensi dengan kreativitas dan inovasi, 5) menciptakan suasana kerja yang nyaman dan nikmat dengan ruh ukhuwah.

Terkait dengan kebijakan kepala madrasah tentang tata kelola madrasah, MTs Negeri 2 Bandar Lampung tidak memiliki kewenangan dalam merekrut guru terutama guru PNS. Hal ini terkadang menyebabkan guru yang diterima di madrasah tersebut 
belum sesuai yang dikehendaki oleh madrasah baik dari kualifikasi maupun kompetensi guru tersebut. Namun madrasah harus melakukan upaya pembinaan dan peningkatan kualifikasi dan kompetensi guru melalui: Pertama, mendorong guru yang belum S1 untuk menyelesaikan studi S1 (semua guru sudah memenuhi kualifikasi S1). Kedua, mendorong guru untuk melanjutkan studi S2. Ada 15 guru yang sudah menyelesaikan studi S2 dan menunggu beberapa guru untuk menyelesaikan studi S2-nya. Ketiga, mendorong guru untuk meningkatkan kompetensinya melalui: (1) mengikuti Diklat atau workshop, baik yang diadakan oleh Kemenag, Diknas maupun madrasah sendiri, (2) kursus bahasa inggris di lembaga pendidikan kursus, (3) belajar sesama kawan guru dalam hal IT seperti mengoperasikan komputer, LCD projector dan memanfaatkan internet untuk pembelajaran.

\section{Perluasan Jaringan Kerjasama Madrasah}

Dalam rangka meningkatkan mutu pendidikan, maka sebuah lembaga pendidikan tidak dapat hidup sendiri dalam menjalankan roda kegiatannya, namun harus ada keterkaitan dengan pihak luar baik sebagai pengawas, pemberi bantuan, maupun pengayoman dari lembaga pemerintah atau swasta. Oleh karena itu, diperlukan suatu jaringan kerja sama agar penyelenggaraan pendidikan di madrasah yang dijalankan berkelanjutan. Jaringan kerjasama dan komunikasi terbukti berperan penting dalam pengembangan penyelenggaraan madrasah. Berbagai jenis jaringan kerjasama dalam pengembangan penyelenggaraan pendidikan di MTsN 2
Bandar Lampung dapat berbentuk antara lain:

Pertama, MTs Negeri 2 Bandar Lampung telah menjalin kerjasama dengan Dinas Pendidikan kota Bandar Lampung dalam bentuk kegiatan MGMP (Musyawarah Guru Mata Pelajaran). MGMP merupakan suatu forum atau wadah profesional guru mata pelajaran yang berada pada suatu wilayah kabupaten/kota/kecamatan/sanggar/ gugus sekolah. Ruang lingkupnya meliputi guru mata pelajaran pada MTs Negeri dan Swasta, baik yang berstatus PNS maupun swasta. Prinsip kerjanya adalah cerminan kegiatan "dari, oleh, dan untuk guru" dari semua madrasah. Atas dasar ini, maka MGMP merupakan organisasi nonstruktural yang bersifat mandiri, berasaskan kekeluargaan, dan tidak mempunyai hubungan hierarkis dengan lembaga lain.

Tujuan diselenggarakannya MGMP di MTsN 2 Bandar Lampung adalah (1) untuk memotivasi guru guna meningkatkan kemampuan dan keterampilan dalam merencanakan, melaksanakan, danmembuat evaluasi program pembelajaran dalam rangka meningkatkan keyakinan diri sebagai guru profesional; (2) untuk meningkatkan kemampuan dan kemahiran guru dalam melaksanakan pembelajaran sehingga dapat menunjang usaha peningkatan dan pemerataan mutu pendidikan; (3) untuk mendiskusikan permasalahan yang dihadapi dan dialami oleh guru dalam melaksanakan tugas sehari-hari dan mencari solusi alternatif pemecahannya sesuai dengan karakteristik mata pelajaran masing-masing, guru, kondisi sekolah, dan lingkungannya; (4) untuk membantu guru memperoleh informasi teknis edukatif yang berkaitan dengan kegiatan ilmu pengetahuan dan 
teknologi, kegiatan kurikulum, metodologi, dan sistem pengujian yang sesuai dengan mata pelajaran yang bersangkutan; dan (5) untuk saling berbagi informasi dan pengalaman dari hasil lokakarya, simposium, seminar, diklat, classroom action research, referensi, dan lain-lain kegiatan profesional yang dibahas bersama-sama.

Saat ini merupakan momentum yang sangat baik apabila guru madrasah, Pemerintah Daerah, DPRD, Kemenag kota/ kab dan pihak-pihak terkait melakukan gerakan bersama-sama memberdayakan MGMP. MTsN 2 Bandar Lampung semakin menyadari betapa strategisnya MGMP terhadap peningkatan mutu pendidikan di madrasah.

Kedua, Menjalin kerja sama dengan LPMP (Lembaga Penjamin Mutu Pendidikan) Propinsi Lampung. Dalam Peraturan Menteri Pendidikan Nasional Nomor 63 tahun 2009, ditegaskan bahwa Pendidikan nasional menjadi tanggung jawab bersama antara Pemerintah, pemerintah daerah, dan masyarakat. Sasaran utama Pendidikan nasional yaitu mutu pendidikan. Mutu pendidikan adalah tingkat kecerdasan kehidupan bangsa yang dapat diraih dari penerapan Sistem Pendidikan Nasional.

Pada tingkat Propinsi yang berhubungan lansung dengan penanganan Pendidikan ini adalah Dinas Pendidikan Provinsi dan Kantor Kemenag Propinsi dan Lembaga Penjaminan Mutu Pendidikan (LPMP) disamping Dinas pendidikan kabupaten Kota yang bertanggungjawab di Kabupaten Kota. Peranan LPMP Riau berfungsi sebagai lembaga penjaminan mutu pendidikian di provinsi Riau. Salah satu program LPMP adalah keterlibatan LPMP dengan pelatihan-pelatihan yang diadakan oleh dinas Pendidikan Propinsi. Nah, MTsN 2 Bandar Lampung sering diikutsertakan dalam pelatihan dan workshop yang diselenggarakan oleh LPMP.

Peningkatan prestasi peserta didik mengalami kemajuan yang sangat signifikan.Prestasi akademik di bidang akademik: Prestasi tingkat nasional pernah diraih oleh 2 (dua) murid MTs Negeri 2 Bandar Lampung dengan mendapat mendali Perak (Biologi) dan Perunggu (Fisika) pada ajang KSM Kompetisi Sain Madrasah Tingkat Nasional tahun 2013. Pada tingkat propinsi, prestasi yang pernah diraih diantaranya: mendapat juara II pada lomba LCT MIPA DAN B. Inggris ke-3, juara 1 lomba PBB putri, juara 2 Pioneering Putra, juara 3 tari bedana, juara 1 lomba hasta karya putra, juara 3 lomba adzan, juara 1 lomba MTQ putra dan juara 2 MTQ putri, juara 1 kaligrafi putra dan putri.

Selain meraih kejuaraan pada perlombaan tingkat propinsi, MTsN juga meraih kejuaraan pada tingkat kota Bandar Lampung, diantaranya:Juara 2 pidato Bahasa Inggris, juara 2 Bilingual, juara 1 MTQ putra dan putri, juara 1 speck kontes putra dan putri, juara 1 Storytelling dan lain lain.

Terakhir, MTsN juga meraih kejuaraan pada tingkat kuarda lampung, diantaranya juara 1 musik klasik, juara 1 perkemahan, juara 1 lomba PBB putra dan putri, juara 2 bilingual, juara I Colonel tongkat, juara 2 pidato bahasa Inggris dan lain lain (Rincian lengkap prestasi yang diraih oleh MTsN 2 Bandar Lampung dapat dilihat pada lampiran).

Kalau dilihat tingkat keberlanjutan almuni MTsN 2 Bandar Lampung, terindikasi 
ada sekitar 99\% lulusan MTs Negeri 2 Bandar Lampung melanjutkan kejenjang pendidikan yang lebih tinggi. Secara umum, lulusan Madrasah Tsanawiyah Negeri (MTsN) 2 dididik untuk menjadi seorang muslim yang beriman, bertaqwa, dan berakhlak mulia yang mempunyai kemampuan untuk bersosialisasi di masyarakat dan dapat memberi contoh dalam lingkungannya.

\section{Pengembangan Kurikulum dan Program Kelas Unggulan}

Untuk mewujudkan tujuan pendidikan nasonal lebih maksimal lagi, diperlukan berbagai strategi peningkatan mutu pendidikan di MTsN 2 Bandar Lampung, diantaranya Kurikulum yang digunakan MTs Negeri 2 Bandar Lampung selain menggunakan kurikulum nasional dan juga adanya beberapa penambahan pengembangan kurikulum seperti penyelenggaraan Kelas Unggul.

MTs Negeri 2 Bandar Lampung telah membuka Kelas Unggulan. Format awal yang dilakukan oleh MTs Negeri 2 Bandar Lampung dalam mewujudkan kelas Unggul adalah melakukan proses re-internalisasi. Re- internalisasi tersebut dalam upaya mengukur potensi, kesiapan dan kekuatan yang dimiliki lembaga.Pada akhirnya, konsep re-internalisasi tersebut menjadi obyektifitas acuan dalam membukan kelas unggul di MTs Negeri 2 Bandar Lampung. Obyektifitas tersebut meliputi recruitmen peserta didik, ketersediaan sarana dan prasarana, ketersediaan guru yang memiliki kualifikasi yang valid sesuai dengan mata pelajaran, khususnya dalam mata pelajaran unggulan, faktor lingkungan, kurikulum, dan kuantitas jam belajar.
MTs Negeri 2 Bandar Lampung semenjak tahun 2006 mulai dibuka Kelas Unggulan dan diterima oleh masyarakat dengan sangat baik. Inovasi ini ternyata dapat menaikkan citra positif madrasah di tengah-tengah masyarakat. Terbukti dari jumlah pendaftar siswa baru setiap tahun meningkat, melampaui kuota yang diterima. Rata-rata yang diterima menjadi siswa baru sebanyak sepertiga dari jumlah pendaftar.

Banyaknya peminat siswa yang masuk ke MTsN 2 Bandar lampung, hal ini tidak terlepas dari terselenggaranya kelas unggulan dan kelas khusus yang disediakan olehpihakmadrasah.Sebagaimanadiketahui bahwa ada 3 (tiga) program pendidikan yang ada di MTSN 2, yaitu: Program Kelas Unggul, Program Kelas Khusus, dan Program Kelas Reguler.

Pertama, Kelas unggul Kelas Unggul adalah kelas yang memiliki keunggulan pada 4 mata pelajaran, yaitu: Bahasa Inggris, Matematika, Bahasa Arab dan Tahfidz Al Qur'an. Kelas unggulan diselenggarakan secara full day school dengan pengertian murid belajar di sekolah dari pukul 07.15 WIB sampai dengan 16.50 WIB kecuali hari sabtu yang belajar hingga pukul 14.00 WIB.

Kedua, Kelas khusus. Kelas Khusus adalah kelas yang memiliki kekhususan untuk mata pelajaran tertentu (masih sesuai dengan kurikulum nasional). Kelas Khusus dibagi kedalam 3 kelas khusus, yaitu: 1) Kelas Khusus A. Memiliki kekhususan pada 2 mata pelajaran, yaitu Bahasa Inggris dan Tahfidz Al Qur'an, 2) Kelas Khusus B. Memiliki kekhususan pada 2 mata pelajaran, yaitu Matematika dan Tahfidz Al Qur'an, 3) Kelas Khusus C. Memiliki kekhususan pada 2 mata pelajaran, yaitu IPA (Ilmu Pengetahuan 
Alam) dan Tahfidz Al Qur'an. Murid-murid yang belajar di Kelas Khusus mulai belajar dari 07.15 WIB sampai dengan 15.30 WIB kecuali hari Sabtu hingga 13.00 WIB.

Ketiga, Kelas Reguler. Kelas Reguler dalah kelas standar yang tidak mengkhususkan pada mata pelajaran tertentu namun tetap sesuai dengan standar kurikulum nasional. Khusus mulai belajar dari 07.15 WIB sampai dengan 14.00 WIB.

\section{Program Kelas Unggulan}

Secara Spesifik, ada 3 (tiga) komponen program unggulan yang dilaksanakan pada kelas unggul MTs Negeri 2 Bandar Lampung, yaitu Keunggulan Akademik, keunggulan Moral, dan keunggulan skill. Masing-masing komponen memiliki program-program khusus.

Pertama, Komponen Akademik meliputi mata pelajaran: Bahasa Inggris dan Bahasa Arab. Tujuannya meningkatkan kemampuan dan keterampilan siswa MTsN 2 Bandar Lampung dalam berbahasa Asing, yaitu Bahasa Inggris dan Bahasa Arab secara aktif.

Kedua, Komponen Moral meliputi: a) Mabit (Malam Bina Iman dan Taqwa), Rihlah, Kelompok Mentoring, Mengontrol amal Ibadah harian. Tujuannya a) siswa diarahkan pada pemahaman agama secara komprehensif (Salimul Aqidah/Aqidahnya Lurus), Shohihul Ibadah (Ibadahnya Baik) dan Matinul Khuluq (Akhlaknya Terpuji), b) Memberikan bimbingan secara lebih intensif dan berkelanjutan dalam kelompokkelompok kecil siswa dan dengan seorang mentor, c) Melakukan pengawasan secara intensif terhadap pelaksanaan amal ibadah harian siswa, baik di sekolah maupun dirumah. Ketiga, Komponen skill meliputi ketrampilan tumah tangga. Tujuannya Siswa dibekali ketrampilan rumah tangga agar kelak menjadi manusia yang berdaya guna dan memiliki sikap kepemimpinan

Secara Umum, untuk memperoleh hasil pembelajaran yang optimal, maka proses pembelajaran dilaksanakan dalam rentang waktu 8 (delapan) jam efektif pembelajaran. Efektifitas pembelajaran pada kelas Unggul MTs Negeri 2 Bandar Lampung dapat dilihat pada tabel sebagai berikut: (1) Hari SenenJum'at Pukul 07.15 s/d 16.00 WIB, dan (2) Hari Sabtu Pukul 07.15 s/d 14.00 WIB.

Penerimaan input kelas unggulan MTs Negeri 2 Bandar Lampung dilakukan dengan mengacu pada terlaksananya proses penerimaan siswa baru yang berkualitas, obyektif dan transparan. Penerimaan siswa di dapat melalui dua jalur penerimaan, yaitu: (1) Jalur Prestasi Akademik adalah jalur penerimaan siswa baru kelas unggul melalui jalur seleksi Rapor kelas 6 SD/MI semester 1 yang memiliki nilai rata-rata 75,00 atau peringkat 10 di kelasnya masing-masing. Yang memenuhi persyaratan tersebut berhak mengikuti seleksi lanjutan. Siswa yang diterima melalui jalur ini sebanyak $60 \%$ dari 40 siswa dalam satu kelas, dan (2) Jalur Reguler adalah jalur penerimaan siswa baru kelas unggul melalui jalur seleksi kelas reguler. Peringkat 1-60 hasil seleksi siswa baru kelas reguler memiliki hak untuk mengikuti seleksi siswa baru kelas unggul. Siswa yang diterima melalui jalur ini sebanyak + $40 \%$ dari 40 siswa dalam satu kelas. Proses seleksi sebagaimana dimaksud di atas, dilaksanakan dengan standar pemenuhan minimal persyaratan sebagai berikut: (a) Test Tertulis untuk menguji tingkat kemampuan akademis siswa sekaligus mengetahui peringkat 
scoring tertinggi yang diperoleh peserta, dan (b) Test Lisan yang meliputi test intelegensi dan kreatifitas yang dimiliki siswa.

\section{Guru Kelas Unggul}

Madrasah yang berkualitas harus memiliki pendidik yang unggul. Artinya, pendidik tersebut harus profesional dalam melaksanakan proses belajarmengajar. Adapun kompetensi guru yang memungkinkan untuk mengembangkan suatu lembaga pendidikan yang unggul menurut trimantara yang dikutip oleh Nur Azizah adalah: kompetensi penguasaan mata pelajaran; kompetensi dalam pembelajaran; 46 Madrasah Inovatif kompetensi dalam pembimbingan; kompetensi komunikasi dengan peserta didik; dan kompetensi dalam mengevaluasi. ${ }^{18}$

Dibutuhkan guru-guru yang berkualitas untuk mencapai keberhasilan pembelajaran di kelas Unggul MTs Negeri 2 Bandar Lampung. Berkualitas tidak saja dari aspek gelar akademik yang dimiliki dan sebagai transformer pembelajaran semata. Untuk itu kualifikasi yang dipilih dan dipersyaratkan bagi guru yang mengajar di kelas unggul MTs Negeri 2 Bandar Lampung, selain kedua syarat utama di atas, standarisasi persyaratan lain yang harus dimiliki adalah: (1) mengajar sesuai dengan latar belakang pendidikannya, (2) memiliki pengalaman mengajar di kelas reguler dengan prestasi yang baik, (3) emiliki Pengetahuan dan pemahaman tentang karakteristik peserta didik yang memilki potensi kecerdasan dan bakat istimewa, (4) memiliki karakteristik

18 Nur Azizah (2012), Madrasah Unggulan, Surabaya: Program Pasca Srajana IAIN Sunan Ampel, h. 8 adil, demokratis, fleksibel, humoris, menghargai, memiliki minat yang luas, perhatian pada masalah yang dihadapi anak, memiliki performance dan sikap yang menarik, (5) memiliki pengetahuan tentang sifat dan kebutuhan anak, (6) memiliki keterampilan dan kemampuan berfikir tingkat tinggi, (7) memiliki pengetahuan tentang kebutuhan kogintif, afektif dan psikomotorik anak cerdas dan berbakat, (8) memilikikemampuan untuk memecahkan masalah secara kreatif, (9) memiliki kemampuan dalam menggunakan strategi mengajar, (10) memiliki kemampuan untuk menggunakan teknik mengajar yang sesuai, dan (11) memiliki kemampuan utnuk melakukan penelitian

Untuk menjamin kualitas dan ketersediaan guru dengan standarisasi di atas, maka lembaga secara institusional memberlakuan sistem penilaian pada proses recruitment guru pada kelas unggul. Proses recruitmen tersebut dilakukan baik secara tertulis (test) dan lisan (wawancara). Proses tersebut dilakukan secara simultan, terprogram, dan terencana sehingga diperoleh hasil yang maksimal.

\section{Kurikulum Kelas Unggul}

Kurikulum yang dipakai dalam kelas unggul adalah kurikulum Nasional dengan muatan lokal yang dimodifikasi pada penekanan materi esensial dan pengayaan materi yang dikembangkan melalui sistem pembelajaran yang dapat memacu dan mewadahi secara keseluruhan anatara spiritual, logika, etika, dan estetika serta mengembangkan kemampuan berfikir holistik, kreatif, sistemik dan sistematis. 
Secara kelembagaan, MTs Negeri 2 Bandar Lampung menyadari bahwa ketersediaan kurikulum yang memenuhi standard di atas untuk sebuah kelas unggul menjadi kunci penting pencapaian kualitas pembelajaran yang dilaksanakan. Program khusus seperti kelas unggul memerlukan diferensiasi kurikulum yang berbeda dengan kelas reguler, mengingat kelas unggul merupakan program yang diperuntukkan bagi anak didik yang memiliki tingkat kecerdasan atau bakat yang tinggi.

Standarisasi diferensiasi kurikulum yang digunakan kelas unggul MTs Negeri 2 Bandar Lampung berpedoman pada: (1) kurikulum yang dikembangkan dalam rangka mengantisipasi kemampuan kecerdasan dan bakat yang dimiliki peserta didik, (2) kurikulum yang harus dapat mewujudkan peserta didik sesuai dengan kemampuan yang dimilikinya, (3) kurikulum yang dirancang untuk dapat menghadapi masalah dan kompleksitas kehidupan yang berubah akibat peningkatan teknologi dan perubahan nilai- nilai sosial, (4) kurikulum yang di rancang untuk mengembangkan kemampuan berfikir kritis dan kemampuan memberikan alasan yang logis serta kemampuan untuk menyelesaikan masalah secara kreatif, (5) kurikulum yang dirancang untuk mengembangkan moral dan kemampuan membuat keputusan secara etis, 6) kurikulum yang dikembangkan dalam rangka mendorong semangat kepemimpinan peserta didik.

Untuk lebih jelasnya format dan struktur kurikulum kelas unggul MTs Negeri 2 Bandar Lampung sebagaimana tabel berikut.
Tabel 1.

Kurikulum MTsN 2 Bandar Lampung

\begin{tabular}{|c|l|c|c|c|}
\hline \multirow{2}{*}{ No } & \multirow{2}{*}{ Mata Pelajaran } & \multicolumn{3}{c|}{ Jumlah jam/kelas } \\
\cline { 3 - 5 } & & VI & VII & IX \\
\hline 1 & Qur'an Hadits & 2 & 2 & 2 \\
\hline 2 & Aqidah Akhlak & 2 & 2 & 2 \\
\hline 3 & Fiqh & 2 & 2 & 2 \\
\hline 4 & SKI & 2 & 2 & 2 \\
\hline 5 & Bahasa Arab & 10 & 10 & 10 \\
\hline 6 & PKn & 2 & 2 & 2 \\
\hline 7 & Bahasa Indonesia & 5 & 5 & 5 \\
\hline 8 & Matematika & 10 & 10 & 10 \\
\hline 9 & IPA Terpadu & 4 & 4 & 4 \\
\hline 10 & Pengetahuan Sosial Terpadu & 4 & 4 & 4 \\
\hline 11 & Seni Budaya & 2 & 2 & 2 \\
\hline 12 & Bahasa Inggris & 10 & 10 & 10 \\
\hline 13 & Penjaskes & 2 & 2 & 2 \\
\hline 14 & Mulok: & 2 & 2 & 2 \\
\hline 15 & a. Bahasa Lampung & 71 & 71 & 71 \\
\hline 16 & b. Keterampilan Rumah Tangga & 2 & 2 & 2 \\
\hline 17 & c. TIK & d. Tahfidzul Qur'an & 2 & 2 \\
\hline 18 & & 2 & 2 \\
\hline
\end{tabular}

Tabel di atas menunjukkan pada beberpa mata peljaran terlihat ada penambahan jumlah jam jika dibandingkan dengan standar yang telah ditentukan. Adapun pelajaran yang mengalami penambahan jumlah jam adalah mata pelajaran Bahasa Arab, Bahasa Inggris dan matematika.

\section{Sumber/bahan pembelajaran}

Bahan belajar yang digunakan di kelas unggul MTs Negeri 2 Bandar Lampung memadukan antara tiga komponen yang saling terkait, yaitu pengetahuan, keterampilan, dan sikap. Bahan ini 
mengandung isi materi (content) baikberupa pengetahuan, keterampilan, proses kreatif atau nilai-nilai yang ingin dikomunikasikan kepada siswa. Secara konkrit bahan-bahan/ sumber-sumber belajar yang digunakan pada kelas unggul MTs Negeri 2 Bandar Lampung meliputi: Buku Kerja, Buku Teks, Modul pembelajaran, Internet, Film/ Video, Komputer, Lembar Kerja Siswa, Laboratorium, Perpustakaan.

\section{Pembelajaran, Metode Dan Strategi}

Is the development new Knowledge, skills, or attitudes as an individual interacts with information and the environment. Mengutip pendapat tersebut, maka konsep pembelajaran yang dikembangkan di kelas unggul MTs Negeri 2 Bandar Lampung diorientasikan pada proses pengembangan pengetahuan baru, keterampilan atau sikap melalui proses interaksi individu dengan informasi dan lingkungan. Pola ini dibangun dengan tujuan untuk menjamin peserta didik belajar melalui siklus pembelajaran yang interaktif dan informatif. Karena sangat diyakini kualitas pembelajaran sangat ditentukan dan dipengaruhi oleh interaksi antara ketersediaan informasi dan lingkungan.

\section{Strategi}

pembelajaran

yang dikembangkan pada kelas unggul MTs Negeri 2 Bandar Lampung adalah mengurutkan peristiwa belajar atau kegiatan pembelajaran dalam sebuah proses pengajaran. Sehingga dengan cara ini ada sebuah ke-Khas-an pada proses pembelajaran, dimana guru tidak memberikan ruang hampa kepada peserta didik, malah sebaliknya terjadi proses pembelajaran yang komunikatifinteraktif antara peserta didik dengan guru, dan peserta didik dengan peserta didik lainnya. Oleh sebab itu strategi pembelajaran pada kelas unggul MTs Negeri 2 Bandar Lampung diorientasikan untuk semaksimal mungkin memberdayakan komponen-komponen pembelajaran yang meliputi: peserta didik, kurikulum, sumber atau bahan pembelajaran, pendidik atau guru, metode serta komponen lingkungan dan situasi. Untuk saat ini, secara konkrit strategi pembelajaran yang digunakan guru pada kelas unggul MTs Negeri 2 Bandar Lampung adalah: presentasi, demonstrasi, pembelajaran cooperative, bermain, simulasi, problem solving, diskusi, drill and practice, penemuan (discovery), serta tutorial.

\section{Media dan Sumber Pembelajaran}

Media dan sumber belajar yang ada saat ini pada kelas unggul MTs Negeri 2 Bandar Lampung meliputi : Pertama, Ssmber belajar seperti : buku paket, buku pelengkap, buku referensi, buku bacaan, majalah, koran, modul, lembar kerja, bulletin, kaset video, VCD, DVD, CD-ROM, dan sebagainya. Kedua, media pembelajaran seperti : kaset recorder, TV, Wireless, Slide projector, LCD, VCD, DVD player, komputer dan sebagainya. Ketiga, adanya sarana Information Tecnology (IT): jaringan internet.

\section{Kendala dan Pendukung Terselenggaranya Program Kelas Unggulan}

Keberadaan kelas ungggulan di madrasah telah menghadirkan fenomena baru. Fenomena baru yang dimaksud adalah ada secercah harapan bahwa madrasah tidak seperti dulu lagi yang dipandang 
sebagai sekolah kelas dua. Terbukti setiap tahun minat masyarakat (siswa) masuk madrasah semakin meningkat. Pada tataran imlementasi program kelas unggulan, terdapat beberapa faktor pendukung dan penghambat terselenggaranya progra kelas unggulan

Faktor pendukung terselenggaranya program kelas unggulan di MTsN 2 Bandar Lampung diantaranya:Pertama, Pelaksanaan program kelas unggulan di MTsN 2 Bandar Lampung didukung dengan adanya jaringan kerjasama tim pengembang kurikulum dan guru dalam wadah MGMP. Pertemuan ini guna menemukan solusi yang terbaik dalam pelaksanaan kurikulum pada program kelas unggulan.

Kedua, Sebagian besar guru yang mengajar pada kelas unggulan merupakan guru yang berkompeten dalam bidangnya sehingga memungkinkan terciptanya kegiatan belajar mengajar yang lebih baik. Ketiga, Peranan komite madrasah yang proaktif dalam memfasilitasi pelaksanaan programkelasunggulanterkaitperencanaan, sosialisasi dan pengawasan pelaksanaan pembelajaran pada kelas unggulan.

Sedangkan faktor penghambat diantaranya: Pertama, secara fisik terkadang siswa mengalami kelelahan dalam mengikuti kelas unggulan karena jumlah jam belajar yang panjang banyak (jam 16,00 sore baru pulang) sehingga akan berdampak kepada hasil belajar siswa, kosentrasi siswa terganggu, kurang fokus, bosan dan jenuh.

Kedua, Siswa program kelas unggulan harus bisa aktif berbahasa Inggris. Namun dalam kenyataannya beberapa siswa belum seperti itu. Ketiga, Berkaitan dengan Reward di kalangan guru kelas unggulan belum merasakan secara nyata bentuk pengharagaan dari kepala madrasah terhadap tugas yang mereka laksanakan. Keempat, Guru-guru yang mengajar pada kelas unggulan belum seruluhnya memberikan layanan sesuai dengan perkembangan teknologi dan informasi. Guru belum maksimal dalam memanfaatkan sumber belajar yang menggunakan multi media

Kelima, Kelas unggulan ini menawarkan konsep untuk membangun kultur akademik dengan mengedepankan keunggulan di bidang imtaq dan imtek sehingga pihak pengelola madrasah perlu melakukan persiapan-persiapan perangkat yang memadai terkait dengan penggunaan multimedia, kelengkapan unit- unit kegiatan siswa (sanggar belajar). Namun di lapangan ditemukan ada beberapa alat -alat perlengkapan laboratorium yang masih belum lengkap bahkan masih ada sebagian perangkat laboratorium belum sepenuhnya dipakai secara maksimal.

\section{PENUTUP}

Berdasarkan hasil penelitian beberapa MTs negeri dan swasta, didapat kesimpulan sebagai berikut: Pertama, Penyelenggaraan program kelas unggulan di MTsN 2 Bandar Lampung bertujuan untuk mencetak kader yang menguasai lmu pengetahuan terutama di bidang ilmu agama sebagai generasi penerus yang berkualitas dan profesional. Kedua, Pelaksanaan kelas unggulan di MTsN 2 Bandar Lampung menghasilkan beberapa prestasi dan itu dibuktikan dengan ketika mengikuti berbagai ajang perlombaan siswa kelas unggulan selalu 
memenanginya terutama di bidang matematika, bahasa dan agama.

Ketiga, faktor pendukung yang paling dominan dalam pelaksanaan program unggulan adalah terbentuknya jaringan kerjasama tim pengembang kurukulum MTsN 2 Bandar Lampung dengan MGMP (Musyawarah Guru Mata Pelajaran), tersedianya guru-guru yang berkompeten, peranan komite madarsah yang proaktif dalam memfasilitasi pelaksanaan program kelas unggulan.

Sedangkan faktor penghambatnya adalah aspek kesiapan siswa yang belum maksimal dalam mengikuti program kelas unggulan (full day) sehingga sebagian siswa mengalami kelelahan dan kejenuhan. Masih ada siswa kelas unggulan yang belum aktif berbahasa Inggris, kurangnya reward dari kepala sekolah terhadap kinerja guru yang mengajar kelas unggulan, dan sebagian guru belum maksimal menggunakan sarana multimedia,

Berdasarkan kesimpulan tersebut diatas dapat disarankan bahwa peningkatan citra madrasah melalui Penyelenggraan program kelas unggulan adalah suatu hal yang positip untuk meningkatkan mutu pendidikan madrasah. Untuk itu kiranya Kementerian Agama khususnya Direktorat Pendidikan Madrasah lebih memperhatikan kebutuhan sarana prasarana pada madrasah yang menyelenggarakan program kelas unggulan sehingga dapat menunjang pembelajaran menjadi lebih baik. Selain itu perlu juga meningkatkan profesionalisme guru-guru yang mengajar di kelas unggulan melalui penyelenggaraan workshop, seminar dan lokakarya.

\section{UCAPAN TERIMA KASIH}

Terima kasih kepada Kepala Puslitbang Pendidikan Agama dan Keagamaan Badan Litbang dan Diklat yang telah memberi kesempatan kepada penulis untuk meneliti, dan kepala MTsN 2 Bandar Lampung termasuk juga seluruh Guru dan Staf Tata Usaha yang turut membantu memberikan data dan informasi, juga kepada Redaktur Jurnal Edukasi atas termuatnya tulisan ini, semoga tulisan ini memberikan wawasan dalam pendidikan agama di Indonesia.

\section{DAFTAR PUSTAKA}

Atmodiwiryo, Soebagio (2000): Manajemen Pendidikan Indonesia, Jakarta: Ardadizya Jaya

Azizah, Nur (2012): Madrasah Unggulan, Surabaya: Program Pasca Srajana IAIN Sunan Ampel.

Hanun, Farida (2013): Laporan Madrasah Unggulan di MTsN Bukit Raya Pekanbaru Riau, Jakarta: Puslitbang Pendidikan Agama dan Keagamaan Badan Litbang dan Diklat Kemeneterian Agama

Hasan, Alwi, dkk (2005): Kamus Besar Bahasa Indonesia, Jakarta : Departemen Pendidikan Nasional Balai Pustaka

Kotler,Philip(2006): B2B Brand Management, Berlin: Springer

Moleong, LexyJ. (2000): Metodologi Penelitian Kualitatif. Cetakan Keenambelas, Bandung: Remaja Rosdakarya

Peraturan Menteri Agama (PMA) no 90 Tahun 2013 Tentang Penyelenggaraan Pendidikan Madrasah 
Sagala, Syaiful (2003): Konsep dan Makna Pembelajaran, Bandung: Alfabeta

Silalahi, Aripin (2006): Program Kelas Unggulan. Jakarta: Sidikalang

Undang-Undang No 20 Tahun 2003 Tentang Sistem Pendidikan Nasional
Utomo, Amin Mudi (2012): Pengelolaan Pendidikan Karakter Kelas Unggulan di SMP Negeri2 Cepu, Surakarta:Universitas Muhammadiyah Surakarta

Zuhairini (2004): Sejarah Pendidikan Islam, Jakarta: Bumi Aksara 